Mark MacCarthy:

\title{
Student Privacy: Harm and Context
}

\begin{abstract}
:
This paper constructs a model of privacy assessment drawn from the context and harm approaches to privacy and applies it to the privacy issues raised by predictive modeling in education. This student privacy assessment involves assessing departures from existing norms of information flow embedded in the social context of education; assessing risks of harm to specific individuals or classes of individuals through unfair or unjustified discrimination; understanding the risk of adverse feedback effects on the aims and purposes of education itself; and the extent to which privacy issues mask more fundamental conflicts over educational values. The paper does not attempt to adjudicate these controversies but rather provides the conceptual and evaluative tools that might facilitate productive discussions.
\end{abstract}

\section{Agenda:}

Introduction

Privacy Frameworks.

Harm

Contextual Integrity

Student Privacy Assessment $\ldots \ldots \ldots \ldots \ldots \ldots$

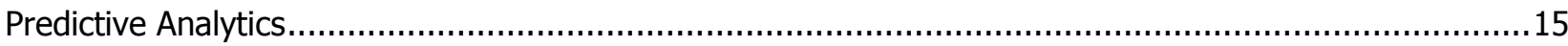

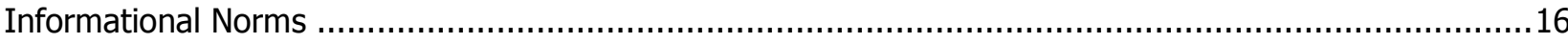

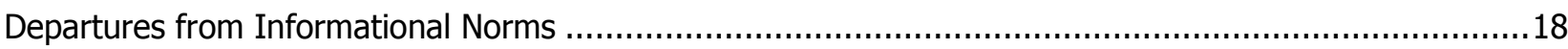

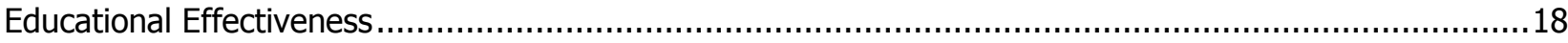

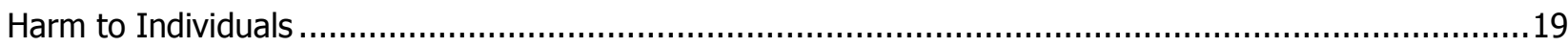

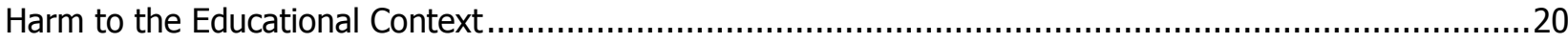

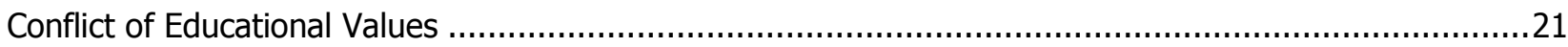

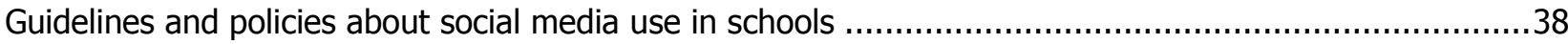

\section{Mark MacCarthy:}

- $\quad$ Adjunct Professor, Communication, Culture \& Technology Program, Georgetown University, 3520 Prospect St. NW, Suite 311, Washington D.C. 20057, USA

- Vice President, Public Policy, Software \& Information Industry Association, 1090 Vermont Avenue, Suite 600, Washington, D.C. 20006

- 留 + 1 202-579-7337, $₫$ maccartm@georgetown.edu 
- Relevant publication:

- Mark MacCarthy "New Directions in Privacy: Disclosure, Unfairness and Externalities." I/S: A Journal of Law and Policy for the Information Society 6.3 (2011) pp. 425-512.

Author's note: The views expressed in this article are those of the author and not necessarily those of Georgetown University, SIIA, or any of its member companies. I thank Robert Gellman, Elana Zeide, and Mary Culnan for their helpful comments on an earlier draft of this paper. 


\section{Introduction}

Recent controversies over increased collection and analysis of student information to improve learning have highlighted concerns about student privacy. This paper looks at these student privacy controversies through the lens of a privacy assessment model drawn from the theory of contextual integrity and the harm framework.

Education is on the verge of dramatic changes in the collection, flow and use of student information made possible by vast improvements in data aggregation, storage capacity and processing tools. Predictive analytics from adaptive learning software can individualize and personalize learning. A combination of demographic and student-learning data can predict which students might fail in a class or drop out of school entirely.

The harm approach would be to use those techniques that seem to cause little real harm and have the potential for substantial improvements in student learning. It seeks to protect individuals from tangible harm associated with information collection and use and treats an information practice as legitimate absent a showing of such harm. It would counsel caution when the use of predictive modeling in education could unfairly affect a student's life chances or involves invidious discrimination that reproduces the prejudices of the past in a new technological form.

In contrast, the theory of contextual integrity counsels caution about transgressive changes that violate intuitive context-relative norms governing information flows. Predictive analytics in education would be suspect to the extent that they depart from informational norms that limit student data collection, restrict student data use to educational purposes and require parental consent and access to records.

A blended framework for student privacy treats both contextual violations and the risk of harm as normatively relevant. It also draws attention to feedback effects that can indirectly threaten educational objectives and the extent to which privacy acts as a proxy for deeper conflicts about the proper goals of education itself.

\section{Privacy Frameworks}

\section{Harm}

In this approach, privacy policy aims to prevent harm to individuals and classes of individuals. Posner 27 provided an important impetus for this style of thinking with an economic analysis of privacy. Cate ${ }^{28}$ distinguishes harmful uses like fraud, which should be prohibited, from harmless uses, which should not be regulated. Privacy rules like consent should be reserved for middle ground cases where the use imposes tangible damage to persons or property. Beales and Muris 29 focus on possible adverse consequences for the consumer and assess the relevant tradeoffs between benefits and costs of information use. MacCarthy ${ }^{30}$ divides information uses into those that are so likely to be socially harmful that they must be prohibited or be subject to opt-in permission

\footnotetext{
27 Richard Posner, The Right of Privacy, 12 Georgia Law Review 393 (1978) pp.393 - 404 available at http://digitalcommons.law.uga.edu/cgi/viewcontent.cgi?article $=1021 \&$ context=lectures pre arch lectures sibley

${ }^{28}$ Fred Cate, Failure of Fair Information Practice Principles, Chapter 13 in Winn, J.K. (Eds), Consumer Protection in the Age of the Information Economy, 2006, pp. 369-375, available at http://www.hunton.com/files/Publication/4100e953-8ce7-47f8-bd912338a896a138/Presentation/PublicationAttachment/cca74554-612c-41e0-934f-1372b8a6afcf/Failure of Fair Information Practice Principles.pdf

29 J. Howard Beales, III \& Timothy J. Muris, Choice or Consequences: Protecting Privacy in Commercial Information 75 U. Chi. L. Rev. 109 2008

${ }^{30}$ Mark MacCarthy. "New Directions in Privacy: Disclosure, Unfairness and Externalities." I/S: A Journal of Law and Policy for the Information Society 6.3 (2011) pp. 425-512
} 
and those so socially beneficial that they must be permitted, or be subject to opt-out permission. Wittes 31 focuses on preventing specific and tangible harms to individuals.

Harm is defined in a number of statutes and regulations. The Federal Trade Commission has the authority to take action against an "unfair" practice, which "causes or is likely to cause substantial injury to consumers which is not reasonably avoidable by consumers themselves and not outweighed by countervailing benefits to consumers or to competition." ${ }^{23}$ The Consumer Financial Protection Board has similar authority to prohibit unfair or abusive practices. ${ }^{33}$ Both agencies have authority under Fair Credit Reporting Act to regulate the use of inaccurate, outdated or irrelevant information in the context of employment, credit granting, and insurance. ${ }^{34}$

Harm also includes invidious discrimination. Title VII of the Civil Rights Act of 1964 bars employment discrimination based on "race, color, religion, sex, or national origin." 35 The Equal Credit Opportunity Act makes it unlawful for any creditor to discriminate on the basis of "race, color, religion, national origin, sex or marital status, or age."36 The Fair Housing Act prohibits housing discrimination "because of race, color, religion, sex, familial status, or national origin." 37 The Genetic Information Nondiscrimination Act of 2008 prohibits health insurance companies and employers from discriminating on the basis of information derived from genetic tests. $^{38}$.

\section{Contextual Integrity}

In contrast, Nissenbaum ${ }^{39}$ treats privacy as an internalized norm embedded in the daily life of people engaged in social pursuits. Privacy is a right to an appropriate flow of information, where appropriate is defined by the context in which the information is generated, disclosed and used. Privacy rules are context-based informational norms that govern the transmission of information and serve to protect the integrity of the context.

Transmission principles are often codified in statutes or vindicated by court decisions but they are not created by these legal procedures, and sometime can conflict with them. Because of this independence from the existing legal framework, informational norms can be the basis for both criticism of existing laws and the establishment of new ones.

This approach provides an intuitive and comprehensive way to think about privacy issues. It explains why improper transfers or uses of information produce outrage. People have strong reactions against privacy intrusions, not because of idiosyncratic preferences, but because privacy intrusions work against widely accepted, entrenched social norms.

The approach also contains a decision heuristic designed to assess new information flows in particular contexts. ${ }^{40}$ Before recommending for or against a new practice it calls for locating applicable informational norms and significant points of departure and asking how the new practice affects the achievement of contextual ends and goals. Ascertaining informational norms involves introspection. As in the case of linguistic intuitions among

\footnotetext{
${ }^{31}$ Benjamin Wittes, "Databuse: Digital Privacy and the Mosaic," Brookings Institution, April 1, 2011, available at http://www.brookings.edu/ /media/Files/rc/papers/2011/0401 databuse wittes/0401 databuse wittes.pdf

3215 U.S.C. 45(n) (2006)

3312 U.S.C. §§ 5481, 5531 \& 5536(a)

${ }^{34} 15$ U.S.C. § 1681a available at http://www.law.cornell.edu/uscode/text/15/1681a

3542 U.S.C. §2000e-2 available at http://www.law.cornell.edu/uscode/text/42/2000e-2

3615 U.S.C. § 1691 available at http://www.law.cornell.edu/uscode/text/15/1691

3742 U.S.C. 3604 available at http://www.law.cornell.edu/uscode/text/42/3604

${ }^{38}$ Pub. L. No. 110-233, 122 Stat. 881 available at http://www.gpo.gov/fdsys/pkg/PLAW-110publ233/pdf/PLAW-110publ233.pdf

${ }^{39}$ Helen Nissenbaum, Privacy in Context: Technology, Policy, and the Integrity of Social Life (Stanford University Press 2010).

${ }^{40}$ Nissenbaum, p. 182
} 
native speakers of a language, the level of agreement can often be extremely high. These norms have a presumptive validity because of their role in upholding the integrity of a context. Still, even if a new practice departs significantly from established informational standards, it can be defended by showing that it achieves contextual goals better or more efficiently.

\section{Student Privacy Assessment}

Nissenbaum ${ }^{41}$ uses her theory of contextual analysis to assess whether school officials should install a new computerized record system and associated analytical software. Because it stores, processes and transmits more information and different kinds of information, it departs from establish informational practices. However, if it promises to improve student learning in a way that is consistent with the goals, values and purposes of education, then it should be allowed. Transmission of information derived from this school information system to outside parties such as prospective employers needs to balance the conflicting needs of separate contexts.

The discussion below broadens and deepens this style of thinking about privacy, incorporating insights from the harm framework and focusing on harm to the educational context and the clash of educational values.

\section{Predictive Analytics}

The Department of Education describes the new computer-based educational resources that record student learning activity and create user models and groupings that improve student learning. ${ }^{42}$ Fain describes online learning systems that recommend the next learning activity and also predict how the student will perform on examinations. 43

The Department of Education distinguishes individualization where instruction is paced to the learning needs of different learner; differentiation where instruction is tailored to the way different learners learn; and personalization where instruction is individualized, differentiated and tailored to the specific interests of learners. ${ }^{44}$ Data about individual students and adaptive software are crucial to each of these alternatives to one-size fits all models of learning. Haedden recommends blended learning models, where students spend part of their time with adaptive software, part of their time with groups of similarly situated students and part of their time receiving instruction from a teacher. ${ }^{45}$

The Department of Education issued a report describing the possible use of biometric information for assessing various psychological characteristics linked to effective learning such as grit, tenacity and perseverance. These readings include posture analysis, skin-conductance sensors, EEG brain-wave patterns, and eye-tracking. ${ }^{46}$

Many of these adaptive learning environments are offered independently of school as online services that can be accessed both by individual students outside the classroom and by students in schools as part of their assigned activities.

\footnotetext{
${ }^{41}$ Nissenbaum, p. 169-171

42 Department of Education, Enhancing Teaching and Learning Through Educational Data Mining and Learning Analytics: An Issue Brief, 2012 http://www.ed.gov/edblogs/technology/files/2012/03/edm-la-brief.pdf

${ }^{43}$ Paul Fain, Intel on Adaptive Learning, Inside Higher Ed, April 4, 2013 http://www.insidehighered.com/news/2013/04/04/gates-foundation-helps-colleges-keep-tabs-adaptive-learning-technology\#disqus thread

${ }^{44}$ Department of Education, Expanding Evidence: Approaches for Measuring Learning in a Digital World, Chapter 2, 2013 available at http://www.ed.gov/edblogs/technology/files/2013/02/Expanding-Evidence-Approaches.pdf

${ }^{45}$ Susan Headden, "The Promise of Personalized Learning," Education Next, Fall 2013 / Vol. 13, No. 4 at http://educationnext.org/thepromise-of-personalized-learning/

${ }^{46}$ Department of Education, Promoting Grit, Tenacity and Perseverance: Critical Factors for Success in the $21^{\text {st }}$ Century, February 2013 p. 41 at http://www.ed.gov/edblogs/technology/files/2013/02/OET-Draft-Grit-Report-2-17-13.pdf
} 
Predictive analytics can also be used to find students at risk of failing a class or dropping out. Some digital textbooks compile information on what students read and calculate an engagement index based on these measures. If their engagement index is very low, then teachers can intervene to take remedial action. ${ }^{47}$

Many schools throughout the country use data to identify students who might be at risk of not graduating. Some of these programs apply the Early Warning Indicator and Intervention System that uses attendance records, behavior problems and course performance to measure dropout risk. ${ }^{48}$ In one school in 2013, onethird of students flagged for missing school got back on track to graduation. Two-thirds of the students who were having behavioral problems made a turnaround. ${ }^{49}$

IBM's Predictive Analytics Solution for Schools and Educational Systems (PASSES) uses a broader range of factors including demographic variables to identify at-risk students. Timely identification enables schools to intervene early in the process. In Hamilton County Board of Education in Tennessee, for example, graduation rates increased by more than 8 percentage points and standardized test scores in math and reading increased by more than 10 percent. ${ }^{50}$ In Mobile County, Alabama the dropout rate has been nudged downward by three percent since the system's introduction. ${ }^{51}$

\section{Informational Norms}

The new technologies of predictive analytics implicate informational norms regarding educational purpose, collection limitation and parental consent and access. Some actual and potential uses of these technologies might depart from these norms.

The educational purpose norm limits the purpose of student information collection and use to education. Students reveal information to their teachers in order to receive instruction. Other institutions in society have no or a significantly lesser claim on this information. This norm protects the professional autonomy of educators, allowing them to set their own practices and methods. Existing law validates this norm. The Family Educational Rights and Privacy Act (FERPA) and its implementing regulations do not permit personal information from education records "to be disclosed for purposes unrelated to education." 52

Predictive modelling used in personalized learning and identification of at-risk students could be used for noneducational purposes. FERPA might well constrain this non-educational use. But the application of FERPA to data derived from online personalized learning programs is not entirely clear. ${ }^{53}$

The collection limitation norm limits the amount and type of information collected from students. Only information that is relevant to education needs to be available to educators. This norm restricts the educational

47 David Streitfeld, "Teacher Knows if You've Done the E-Reading," New York Times, April 8, 2013 at http://www.nytimes.com/2013/04/09/technology/coursesmart-e-textbooks-track-students-progress-for-teachers.html?pagewanted=all\& $r=1 \&$

48 Mary Bruce and John M. Bridgeland, "The Use of Early Warning Indicator and Intervention Systems to Build a Grad Nation," Johns Hopkins University November 2011 at http://www.civicenterprises.net/MediaLibrary/Docs/on track for success.pdf

49 Sammy Mack, "Putting Student Data To The Test To Identify Struggling Kids," NPR, April 08, 2014 at http://www.npr.org/2014/04/08/300587823/putting-student-data-to-the-test-to-identify-struggling-kids

${ }^{50}$ IBM, IBM Predictive Analytics Solution for Schools and Educational Systems,

http://www-01.ibm.com/common/ssi/cgi-bin/ssialias?htmlfid=YTS03068USEN\&appname=wwwsearch

51 IBM, Mobile County Public Schools: Analytical insights help keep students on track, IBM, 2011 p. 5 available at http://www.ibm.com/smarterplanet/us/en/leadership/mobilecounty/assets/pdf/IBM MobileCounty.pdf

52 Department of Education, Family Educational Rights and Privacy; Final Rule, Federal Register Vol. 76, No. 232, December 2, 2011 p. 75608 at http://www.gpo.gov/fdsys/pkg/FR-2011-12-02/pdf/2011-30683.pdf

53 Department of Education, Protecting Student Privacy While Using Online Educational Services: Requirements and Best Practices, February 2014 at http://ptac.ed.gov/sites/default/files/Student\%20Privacy\%20and\%200nline\%20Educational\%20Services\%20\%28February\%202014\%29.pdf 
enterprise to its task of instruction and prevents educational institutions from using intrusive information gathering to engage in wider social control. The Protection of Pupil Rights Amendment (PPRA) validates this collection limitation norm by requiring prior written parental consent for the collection of sensitive information including political affiliations, psychological problems, sex behavior or attitudes. ${ }^{54}$

Personalized learning applications raise concerns about excessive collection of student information. Learning devices, computer software and online instructional resources capture vast amounts of highly detailed information about students. This erodes the technological constraints limiting what educators can learn about students. Previously, teachers had no way to know how long a student took to read a book or what his or her eye movements were. They did not know about heart rate or breathing patterns or skin resistance. Now educators can know these things regardless of any proven relevance to education. Even though, as the Department of Education says, "our ability to track factors that influence learning has outpaced careful research on which factors are worth tracking, ${ }^{\prime \prime 5}$ the pressure to explore these new technological possibilities means that information gathering will likely go beyond the existing collection limitation norm.

Parental consent is usually required before schools distribute student information to third parties not involved in their student's education. This norm works together with the educational purpose norm to limit the uses of student information. Several laws reinforce this norm. PPRA requires prior written parental consent before allowing the collection of student information for marketing purposes. ${ }^{56}$ FERPA requires parental consent for dissemination of student information to third parties except when the third party functions as a school official; ${ }^{57}$ or is conducting an audit or evaluation of an educational program; ${ }^{58}$ or a study for an educational institution. ${ }^{59}$ The Children's Online Privacy Protection Act (COPPA) requires online learning applications directed to children under 13 to obtain verifiable parental consent before collecting personal information. ${ }^{60}$

Potential departures from the parental consent norm involve the wide range of information that is made collected in state level databases for use in personalized learning and some student information collected by online learning applications. ${ }^{61}$

Under the parental access norm, parents have a right to see their children's educational records and rectify any inaccuracies. This norm helps make educational institutions more accountable to parents. FERPA reinforces this norm by providing for parental rights to inspect, review and amend educational records. ${ }^{62}$ COPPA also requires online educational applications targeted to children under 13 to provide parental access to the records that they maintain on children. ${ }^{63}$

Parents do not necessarily have guaranteed access to records in the case of online educational programs for those 13 and over and for student information maintained by school districts and state educational departments.

\footnotetext{
${ }^{54} 20$ U.S.C. § $1232 \mathrm{~h}(\mathrm{~b})$

55 Department of Education, Expanding Evidence: Approaches for Measuring Learning in a Digital World, Chapter 2, 2013 p. 32 available at http://www.ed.gov/edblogs/technology/files/2013/02/Expanding-Evidence-Approaches.pdf

${ }^{56} 20$ U.S.C. $\S 1232 \mathrm{~h}(\mathrm{c})(2)(\mathrm{C})(\mathrm{i})$

5734 CFR § 99.31(a)(1)(i)

${ }^{5} 20$ U.S.C. $1232 \mathrm{~g}(\mathrm{~b})(1)(\mathrm{C})$, (b)(3), and (b)(5)

5920 U.S.C. $\S 1232 \mathrm{~g}(\mathrm{~b})(1)(\mathrm{F})$

${ }^{60}$ Federal Trade Commission, Complying with COPPA: Frequently Asked Questions, April 2014 at http://www.business.ftc.gov/documents/0493-Complying-with-COPPA-Frequently-Asked-Questions

${ }^{61}$ Department of Education, Protecting Student Privacy While Using Online Educational Services: Requirements and Best Practices, February 2014 at http://ptac.ed.gov/sites/default/files/Student\%20Privacy\%20and\%200nline\%20Educational\%20Services\%20\%28February\%202014\%29.pdf

6234 CFR § $99.10-99.12 ; \S 99.20-99.22$

${ }^{63}$ Federal Trade Commission, Complying with COPPA: Frequently Asked Questions, April 2014 at http://www.business.ftc.gov/documents/0493-Complying-with-COPPA-Frequently-Asked-Questions
} 
So there is a risk that predictive modelling information used in these cases will depart from the parental access norm.

\section{Departures from Informational Norms}

The possibility of a departure from informational norms does not mean that there is an actual breach of informational norms. For instance, in the Mobile County program for identifying at-risk students parental consent was required for participation and parental access was granted to the database used for the analysis.

The risk that information collection practices involved in predictive modelling might depart significantly from these informational norms explains why Morozov objects to the "creepiness" involved in monitoring what students read ${ }^{64}$ and Robbins rejects "the appalling invasion of privacy" involved in biometric monitoring. ${ }^{65}$

The demise of inBloom is also connected to public concerns that the collection of student information has gone beyond accepted educational norms. InBloom, a private non-profit organization supported by the Gates Foundation, aimed to aggregate a wide range of student information for state education departments and local school districts. Their intent was to make this data available to third party service providers to develop educational resources such as dashboards and personalized learning applications. Initially they won contracts from school districts and state education departments around the country. But in 2013, privacy concerns about the increased collection and use of student data led many of their partner educational institutions to withdraw from the program. In 2014, New York State passed a law barring the state education department from continuing its association with inBloom. Shortly after in April 2014 that inBloom shut down. ${ }^{66}$

The informational norms of collection limitation, purpose limitation and parent access and consent have a role in supporting key educational values. They help sustain a delicate balance among the different values, purposes and ends involved in education. For this reason, they are not merely traditional ways of doing things. They are presumptively valid restrictions on how student information should and should not be used. The fact that the new practices involving predictive modelling might depart from these presumptively valid standards means that they face a burden of proof to demonstrate that their use promises to achieve educational objectives.

\section{Educational Effectiveness}

More effective educational technology that furthers the objectives and values of the educational context could justify departures from existing informational norms. Systems of adaptive learning have been shown to be effective in increasing student learning. The Department of Education concluded: "...studies have shown that students taught by carefully designed systems used in combination with classroom teaching can learn faster and translate their learning into improved performance relative to students receiving conventional classroom instruction. ${ }^{167}$ As noted above, the programs for identification of at-risk students, combined with effective and timely intervention programs have real, measureable effects, increasing student performance on tests and decreasing dropout rates

\footnotetext{
${ }^{64}$ Evgeny Morozov, In Soviet Russia, Book Reads You: The Creepiness of Software that Monitors Students' E-Reading, Future Tense, November 27, 2012 at http://www.slate.com/articles/technology/future tense/2012/11/coursesmart analytics whispercast the danger of software that monitors students.html

65 Jane Robbins, Common Core and Data Collection, Truth in American Education, April 7, 2014 available at http://truthinamericaneducation.com/privacy-issues-state-longitudinal-data-systems/common-core-data-collection/

${ }^{66}$ Benjamin Herold, "InBloom To Shut Down Amid Growing Data-Privacy Concerns," Education Week, April 21, 2014 at http://blogs.edweek.org/edweek/DigitalEducation/2014/04/inbloom to shut down amid growing data privacy concerns.html ; Natasha Singer, inBloom Student Data Repository to Close, New York Times, April 21, 2014 http://bits.blogs.nytimes.com/2014/04/21/inbloom-studentdata-repository-to-close/

${ }^{67}$ Department of Education, Expanding Evidence: Approaches for Measuring Learning in a Digital World, Chapter 2, 2013 p. 28 available at http://www.ed.gov/edblogs/technology/files/2013/02/Expanding-Evidence-Approaches.pdf
} 
The Executive Office of the President highlighted the benefits of moving beyond traditional student data for research into learning: "Data from a student's experience . . . can be precisely tracked, opening the door to understanding how students move through a learning trajectory with greater fidelity, and at greater scale, than traditional education research is able to achieve." ${ }^{\prime 68}$

There is no absolute standard on how much information on effectiveness is needed to overcome the presumption against departures from social norms of information flow. Mere assertion that student learning might be improved is not enough. Proof beyond a shadow of a doubt is too high a standard. Moreover, evidence varies by type of personalized learning method. Because evidence that certain characteristics predispose students to learn better from different modes of presentation is "sparse, ${ }^{169}$ techniques that rely on this notion are not supported. Biometric measurements are not widely used because they depend on constrained tasks in digital learning environments, are not yet practical in the classroom and evidence of a connection to learning outcomes is just emerging. ${ }^{70}$ Practitioners and policymakers need to evaluate the extent to which personalized learning systems and identification of at-risk students have demonstrated enough improvement in student learning so that they pass this particular stage in the assessment process.

\section{Harm to Individuals}

Personalized learning techniques pose some risks of individual harm, depending on how they are used. True personalization would not just pace students more effectively or vary educational methods, but would provide different content and potentially different educational opportunities based on an assessment of the student's capabilities. These assessments might be faulty and hard to reverse and so might improperly restrict educational opportunities. Students who are identified as at risk might be stigmatized as less capable which can cause the students to behave in less capable ways and cause teachers to treat the students as if they are less capable. The identification of students at risk might not allow students to remove any harmful record of their failures though improved activity.

Predictive modelling used in eligibility decisions usually raises the possibility of harmful discrimination. ${ }^{71}$ Harmful discrimination includes "unjustified discrimination" where faulty data or algorithms put people in the wrong category in error or where they are in the right category, but the category is a protected category like gender, age, or ethnicity which are legally impermissible bases for decision making. "Unfair discrimination" is also objectionable because it deprives people of equal opportunity, or burdens them with additional risk. ${ }^{72}$

Personalized learning techniques raise these risks of data discrimination in education. The algorithms used to select at-risk students might be proxies for protected classes, so that they reinforce historical patterns of discrimination. The predictive factors in personalized learning algorithms might be arbitrary or unfair. Secret factors or scoring techniques might render algorithmic decision making in personalized learning opaque and unaccountable.

\footnotetext{
${ }^{68}$ Executive Office of the President, Big Data: Seizing Opportunities, Preserving Values, 2014 at http://www.whitehouse.gov/sites/default/files/docs/big data privacy report 5.1.14 final print.pdf

${ }^{69}$ Department of Education, Expanding Evidence: Approaches for Measuring Learning in a Digital World, Chapter 2, 2013 p. 34 available at http://www.ed.gov/edblogs/technology/files/2013/02/Expanding-Evidence-Approaches.pdf

70 Department of Education, Promoting Grit, Tenacity and Perseverance: Critical Factors for Success in the $21^{\text {st }}$ Century, February 2013 p. 45 at http://www.ed.gov/edblogs/technology/files/2013/02/OET-Draft-Grit-Report-2-17-13.pdf

71 Cynthia Dwork \& Deirdre K. Mulligan, "It's Not Privacy and It's Not Fair," 66 Stan. L. Rev. Online 35, September 3, 2013 at http://www.stanfordlawreview.org/online/privacy-and-big-data/its-not-privacy-and-its-not-fair; Tal Zarsky, "Transparent Predictions," University of Illinois Law Review, Vol. 2013, No. 4, 2013. Available at http://ssrn.com/abstract=2324240; Oscar Gandy, The Panoptic Sort Westview Press, 1993, pp. 200-01

72 Mireille Hildebrandt and Bert-Jaap Koops, "The Challenges of Ambient Law and Legal Protection in the Profiling Era," Modern Law Review 73, no. 3 (2010): 428-460, p. 436
} 
These risks can be mitigated, reduced or eliminated. One response to these concerns would be to validate the personalized learning algorithms used so as to minimize the risk of inaccuracy. Another would be to refrain from using patterns in data for personalized learning and at-risk decisions unless these connections were supported with "underlying theories of causation." ${ }^{173}$ Another would be to use statistical tests to detect whether factors in models are for protected classes. The Federal Trade Commission, for example, used statistical techniques to assess whether credit insurance scores were proxies for protected classes in setting automobile insurance rates. ${ }^{74}$ Improved transparency practices can also respond to concerns about secrecy and unaccountability. ${ }^{75}$

\section{Harm to the Educational Context}

If personalized learning assessments or at-risk identifications become parts non-educational eligibility decisions, the risk of harm to individuals increases significantly. Students could lose access to employment, insurance, credit, or housing. To the extent that personalized learning assessments or at-risk identifications are predictive of competence in these other areas, however, there will be a rational basis to use it for these purposes

Student information used in these contexts would be subject to the range of protections preventing unfair discrimination and decisions derived from inaccurate, outdated, or irrelevant information. But the risk would exist that accurate information from personalized learning assessments or at-risk identifications would deny students significant opportunities later in life.

Evaluating the reasonableness of this risk involves assessing not only the possible harm to individuals but also the risk of feedback effects that can produce harm to the educational context. Nissenbaum draws attention to the possibility that changes in information flows might not only create "possible injustices or harms to individuals" but also harm the "fundamental commitment of the context." 76

Harm to a context can take place when harm to individuals from information use or violations of entrenched informational norms cause people to withdraw from the context in ways that make it harder to achieve the intrinsic goals of the context. For instance, harm to the medical and scientific research contexts justified the legal ban on genetic discrimination. Fears of genetic discrimination "dissuade patients from volunteering to participate in the research necessary for the development of new tests, therapies and cures." ${ }^{17}$

In a similar way, legal rules and social norms protect the confidentiality of information shared with doctors, lawyers, priests, and psychiatrists because these context would quickly unravel if this confidential information were regularly transferred to police, insurance companies, employers and others seeking to enforce laws or make eligibility decisions about the data subject. External use of social network information for eligibility decisions like employment, insurance underwriting or credit granting might harm these contexts as people share less information on social networks for fear of how it might be used against them.

Releasing personalized learning assessments and at-risk identifications outside of education poses a significant risk of harm to the educational context. Students and parents will want to use the new technologies of personalized learning and early warning systems only if they are assured that their use will not be used against them in other contexts. Employers, advertisers, and insurance companies might have perfectly good reasons to want

\footnotetext{
${ }^{73}$ Nissenbaum, p. 209

${ }^{74}$ Federal Trade Commission, Credit-Based Insurance Scores: Impacts On Consumers Of Automobile Insurance, July 2007 at http://www.ftc.gov/sites/default/files/documents/reports/credit-based-insurance-scores-impacts-consumers-automobile-insurance-reportcongress-federal-trade/p044804facta report credit-based insurance scores.pdf

${ }^{75}$ Pam Dixon and Robert Gellman, The Scoring of America, World Privacy Forum, 2014 at http://www.worldprivacyforum.org/wp-content/uploads/2014/04/WPF Scoring of America April2014 fs.pdf

${ }^{76}$ Nissenbaum, p. 176

77 National Genome Research Institute, Genetic Discrimination at http://www.genome.gov/10002077
} 
access to the student information generated by these predictive models - such information might increase the accuracy and efficiency of their business decisions. But using this kind student information for these noneducational purposes might undermine the trust that students and parents have in the integrity of the educational system. They might respond by avoidance, hostility and withdrawal.

A balance needs to be struck, but with a strong presumption in favour of the current legal regime's prohibition on the sharing of student information outside the educational context. Departing from this presumption in certain special cases might be justified but it would take expert substantive knowledge to understand the goals of education and the likely effects of the external use of new technology on these goals.

\section{Conflict of Educational Values}

Education is undergoing polarizing re-thinking including controversial struggles over common core standards, teacher assessment, privatization through school choice, the role of high-stakes testing, the importance of class size, the role of teachers and devices, identification and closing of problem schools, the extent to which education itself proceeds through schools, the design of schools into classes divided by age, the role of schools as providers of workers to business, and the objective of teaching competencies rather than grading performance in courses.

Often the collection and use of student information is crucial in forwarding elements in these educational reform efforts. For instance, Secretary of Education Arne Duncan connected increased data collection to teacher effectiveness assessments, data-driven school closings, common core standards, and assessment of student programs by student earnings as an adult. ${ }^{78}$ Those opposed to these education reforms resist the call for increases in data collection about students as a way to undermine the reform efforts that they oppose.

To some critics, personalized learning seems to be the opposite of good educational practices. Brigg (2014) argues "...it dehumanizes those being judged, as well as those making the judgments. It substitutes calculation for human judgment on what should be very sensitive human issues, and thus treats those profiled as objects, as collections of facts, rather than as persons." ${ }^{\prime 79}$ Haimson objects to the inBloom data collection initiative because "putting kids on computers and subjecting them to canned software programs ...is yet another way in which children's education is being mechanized, depersonalized..." ${ }^{\prime 80}$

Warner criticizes adaptive learning because "...it turns learning into a program we navigate, the software telling us what we need every step of the way. We wait for the software to tell us what's next. It removes agency from the equation, telling us what we "need," rather than letting the individual ask and then answer their own questions." 81

Commercialization is also a hidden driver of student privacy controversies. Cody articulates this anti-commercialism: "It is understandable why people who have made their fortunes on the transformation of commerce and industry through the almighty combination of computers, software, data and the internet would project a similar revolution in our schools." ${ }^{12}$

\footnotetext{
${ }^{78}$ Arne Duncan, Robust Data Gives Us the Roadmap to Reform, June 9, 2009 at http://www2.ed.gov/news/speeches/2009/06/06082009.pdf

79 Saga Brigg, "Big Data in Education: Big Potential or Big Mistake?" Innovation Excellence, January 29, 2014 http://www.innovationexcellence.com/blog/2014/01/29/big-data-in-education-big-potential-or-big-mistake/\#sthash.HQMT1MmF.dpuf

${ }^{80}$ Leonie Haimson, "Statement on inBloom's overdue demise," NYC School Parents April 21, 2014 at http://nycpublicschoolparents.blogspot.com/2014/04/statement-on-inblooms-demise.html

81 John Warner, "We Don't Need No Adaptive Learning," Inside Higher Ed, April 4, 2013 http://www.insidehighered.com/blogs/just-visiting/we-dont-need-no-adaptive-learning\#ixzz31nbs1jz5

${ }^{82}$ Anthony Cody, "The Classroom of the Future: Student-Centered or Device-Centered?" Education Week Teacher, April 6, 2014 http://blogs.edweek.org/teachers/living-in-dialogue/2014/04/the classroom of the future st.html
} 
Many feel that advertising and marketing commercial products has no place in schools. But some local schools and school districts allow it in school billboards, newspapers, yearbooks, and cafeterias. This conflict over advertising does not implicate student privacy unless the ads are targeted using student information, a practice barred by FERPA's prohibition on non-educational uses of student information and addressed directly in the Markey-Hatch draft student privacy bill ${ }^{83}$ and the Student Online Personal Information Protection Act introduced in the California Senate in February 2014. ${ }^{84}$

There is a question whether student information should be used for developing and improving educational products and services using the same kind of analytic engines that power commercial music and book recommendations for online customers. This dispute turns on differing fundamental attitudes toward commercial activity in education and less about the proper norms for student information flows.

A key insight of the combined harm and context framework used in this paper is that disagreement on informational norms might relate to disagreements about the underlying values of education. Apparent conflicts about the privacy implications of data use by a new educational technology might reflect incompatible visions of what the education should be all about. By focusing our attention of these underlying values as part of a privacy assessment, this way of thinking about privacy enables us to see when it is that privacy is acting as a proxy for more basic clashes in values.

\section{References}

J. Howard Beales, III \& Timothy J. Muris, Choice or Consequences: Protecting Privacy in Commercial Information 75 U. Chi. L. Rev. 1092008

Saga Brigg, "Big Data in Education: Big Potential or Big Mistake?" Innovation Excellence, January 29, 2014 http://www. innovationexcellence.com/blog/2014/01/29/big-data-in-education-big-potential-or-big-mistake/\#sthash.HQMT1MmF.dpuf

Mary Bruce and John M. Bridgeland, "The Use of Early Warning Indicator and Intervention Systems to Build a Grad Nation," Johns Hopkins University November 2011 at http://www.civicenterprises.net/MediaLibrary/Docs/on_track_for_success.pdf

Fred Cate, Failure of Fair Information Practice Principles, Chapter 13 in Winn, J.K. (Eds), Consumer Protection in the Age of the Information Economy, 2006, pp. 369-375, available at http://www. hunton.com/files/Publication/4100e953-8ce7-47f8-bd91-2338a896a138/Presentation/PublicationAttachment/cca74554-612c-41e0-934f-1372b8a6afcf/Failure_of_Fair_Information_Practice_Principles.pdf

Anthony Cody, "The Classroom of the Future: Student-Centered or Device-Centered?" Education Week Teacher, April 6, 2014 http://blogs.edweek.org/teachers/living-in-dialogue/2014/04/the_classroom_of_the_future_st.html

Pam Dixon and Robert Gellman, The Scoring of America, World Privacy Forum, 2014 at http://www.worldprivacyforum.org/wp-content/uploads/2014/04/WPF_Scoring_of_America_April2014_fs.pdf

Cynthia Dwork \& Deirdre K. Mulligan, It's Not Privacy and It's Not Fair, 66 Stan. L. Rev. Online 35, September 3, 2013 at http://www.stanfordlawreview.org/online/privacy-and-big-data/its-not-privacy-and-its-not-fair

Arne Duncan, Robust Data Gives Us the Roadmap to Reform, June 9, 2009 at http://www2.ed.gov/news/speeches/2009/06/06082009.pdf

Department of Education, Enhancing Teaching and Learning Through Educational Data Mining and Learning Analytics: An Issue Brief, 2012 http://www.ed.gov/edblogs/technology/files/2012/03/edm-la-brief.pdf

\footnotetext{
${ }^{83}$ Senators Ed Markey and Orrin Hatch, S. Protecting Student Privacy Act of 2014, Discussion Draft, May 12, 2014 at http://www.markey.senate.gov/imo/media/doc/2014-05-12 StudentPrivacy DiscussionDraft.pdf

${ }^{84}$ Senator Darrell Steinberg, SB 1177, Student Online Personal Information Protection Act, February 20, 2014 at http://www.leginfo.ca.gov/pub/13-14/bill/sen/sb 1151-1200/sb 1177 bill 20140220 introduced.pdf
} 
Department of Education, Expanding Evidence: Approaches for Measuring Learning in a Digital World, Chapter 2, 2013 available at http://www.ed.gov/edblogs/technology/files/2013/02/Expanding-Evidence-Approaches.pdf

Department of Education, Promoting Grit, Tenacity and Perseverance: Critical Factors for Success in the 21st Century, February 2013 at http://www.ed.gov/edblogs/technology/files/2013/02/OET-Draft-Grit-Report-217-13.pdf

Department of Education, Protecting Student Privacy While Using Online Educational Services: Requirements and Best Practices, February 2014 at http://ptac.ed.gov/sites/default/files/Student\%20Privacy\%20and\%200nline\%20Educational\%20Services\%20\%28February\%202014\%29.pdf

Executive Office of the President, Big Data: Seizing Opportunities, Preserving Values, 2014 at http://www.whitehouse.gov/sites/default/files/docs/big_data_privacy_report_5.1.14_final_print.pdf

Paul Fain, Intel on Adaptive Learning, Inside Higher Ed, April 4, 2013 http://www.insidehighered.com/news/2013/04/04/gates-foundation-helps-colleges-keep-tabs-adaptive-learning-technology\#disqus_thread

Federal Trade Commission, Credit-Based Insurance Scores: Impacts On Consumers Of Automobile Insurance, July 2007 at http://www.ftc.gov/sites/default/files/documents/reports/credit-based-insurance-scores-impacts-consumers-automobile-insurance-report-congress-federal-trade/p044804facta_report_creditbased_insurance_scores.pdf

Oscar Gandy, The Panoptic Sort Westview Press, 1993

Leonie Haimson, "Statement on inBloom's overdue demise, "NYC School Parents April 21, 2014 at http://nycpublicschoolparents.blogspot.com/2014/04/statement-on-inblooms-demise.html

Susan Headden, "The Promise of Personalized Learning," Education Next, Fall 2013 / Vol. 13, No. 4 at http://educationnext.org/the-promise-of-personalized-learning/

Benjamin Herold, "Inbloom To Shut Down Amid Growing Data-Privacy Concerns, Education Week, April 21, 2014 at http://blogs.edweek.org/edweek/DigitalEducation/2014/04/inbloom_to_shut_down_amid_growing_data_privacy_concerns.html

Mireille Hildebrandt and Bert-Jaap Koops, "The Challenges of Ambient Law and Legal Protection in the Profiling Era," Modern Law Review 73, no. 3 (2010): 428-460, p. 436

IBM, IBM Predictive Analytics Solution for Schools and Educational Systems, http://www-01.ibm.com/common/ssi/cgi-bin/ssialias?htmlfid=YTS03068USEN\&appname=wWwsearch

IBM, Mobile County Public Schools: Analytical insights help keep students on track, IBM, 2011 available at http://www.ibm.com/smarterplanet/us/en/leadership/mobilecounty/assets/pdf/IBM_MobileCounty.pdf

Mark MacCarthy "New Directions in Privacy: Disclosure, Unfairness and Externalities. "I/S: A Journal of Law and Policy for the Information Society 6.3 (2011) pp. 425-512.

Sammy Mack, "Putting Student Data To The Test To Identify Struggling Kids, "NPR, April 08,2014 at http://www.npr.org/2014/04/08/300587823/putting-student-data-to-the-test-to-identify-struggling-kids

Evgeny Morozov, In Soviet Russia, Book Reads You: The Creepiness of Software that Monitors Students' EReading, Future Tense, November 27, 2012 at http://www.slate.com/articles/technology/future_tense/2012/11/coursesmart_analytics_whispercast_the_danger_of_software_that_monitors_students.htm/

Helen Nissenbaum, Privacy in Context: Technology, Policy, and the Integrity of Social Life (Stanford University Press 2010).

Richard Posner, The Right of Privacy, 12 Georgia Law Review 393 (1978) pp.393 - 404 available at http://digitalcommons.law.uga.edu/cgi/viewcontent.cgi?article=1021\&context=lectures_pre_arch_lectures_sibley

Jane Robbins, Common Core and Data Collection, Truth in American Education, April 7, 2014 available at http://truthinamericaneducation.com/privacy-issues-state-longitudinal-data-systems/common-core-datacollection/

Natasha Singer, "inBloom Student Data Repository to Close," New York Times, April 21, 2014

http://bits.blogs.nytimes.com/2014/04/21/inbloom-student-data-repository-to-close/ 
David Streitfeld, "Teacher Knows if You've Done the E-Reading," New York Times, April 8, 2013 at http://www.nytimes.com/2013/04/09/technology/coursesmart-e-textbooks-track-students-progress-forteachers. htm/?pagewanted $=a l l \& \_r=1 \&$

John Warner, "We Don't Need No Adaptive Learning, "Inside Higher Ed, April 4, 2013 http://www.insidehighered.com/blogs/just-visiting/we-dont-need-no-adaptive-learning\#ixzz31nbs1jz5

Benjamin Wittes, "Databuse: Digital Privacy and the Mosaic," Brookings Institution, April 1, 2011, available at http://www.brookings.edu/ /media/Files/rc/papers/2011/0401_databuse_wittes/0401_databuse_wittes.pdf

Tal Zarsky, Transparent Predictions (September 10, 2013). University of Illinois Law Review, Vol. 2013, No. 4, 2013. Available at http://ssrn.com/abstract $=2324240$ 